\title{
Performance Efficiency of Electrocoagulation Adsorption Process of Oxyfluorfen Herbicide from Aqueous Solutions Using Different Anodes
}

Nasser M Ghalwa*, Ahmed Z Musabeh and Nader B Farhat

Department of Chemistry, Faculty of Science, Al-Azhar University-Gaza, Gaza Strip, Palestine

\begin{abstract}
The main purpose of this work was to assess the removal of the herbicide oxyfluorfen and chemical oxygen demand (COD) in aqueous solution using the electrocoagulation process. The results showed that the maximum removal efficiency for oxyfluorfen and COD were (98.5\% and $90 \%),(99.2 \%$ and $85 \%)$ and $(96.1 \%$ and $70.5 \%)$ at 30 min by using

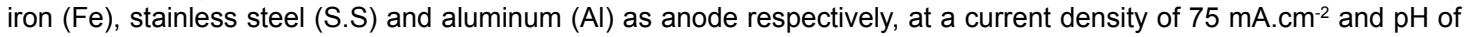
5.8. The energy consumption in the electrocoagulation process at optimum conditions $\left(15.9,16.65\right.$ and $\left.14.1 \mathrm{KWh} / \mathrm{m}^{3}\right)$ using $\mathrm{Fe}, \mathrm{SS}$ and $\mathrm{Al}$ electrodes respectively. The adsorption of oxyfluorfen preferably fitting the Freundlich adsorption isotherm. The adsorption process follows the first order kinetic model with good correlation.
\end{abstract}

Keywords: Electrocoagulation; Electrodes; Herbicide; Oxyfluorfen; Adsorption; Kinetics

\section{Introduction}

In the last decades, the use of agrochemicals has been a common practice in intense agriculture, which has considerably increased pollution problems of surface and ground water [1]. Oxyfluorfen [2-chloro-1-(3-ethoxy-4-nitrophenoxy)-4-(trifluromethyl)-benzene], a member of the herbicide class nitrodiphenyl ether, has a high degree of weed control and great versatility of application [2]. Oxyfluorfen is considered to be highly resistant to degradation in water [3]. And has Potential adverse effects on the ecosystem even if present at very low concentration levels, where the half-life of oxyfluorfen ranged from 72 to 160 days for water [4,5]. Many conventional methods have been successfully applied for the efficient removal of oxyfluorfen from water sources such as adsorption [6], advanced oxidation [7], photo Fenton [8], $\mathrm{UV} / \mathrm{H}_{2} \mathrm{O}_{2}$ [9], and biological treatment [10]. In recent years novel methods for water purification have been developed including chemical, electrochemical and photochemical processes [11]. In this scenario, the electrocoagulation (EC) is an electrochemical has attracted increasing interest as a promising powerful method for efficiently removing pesticides from water such as Malathion [12], methyl parathion, atrazine and triazophos [13], imidacloprid and chlorpyrifos [14], and 2,4- dichlorophenoxyacetic Acid (2,4-D) [15].

The aim of this study is to conduct an experimental investigation on the removal of a oxyfluorfen and COD from the aqueous solution using the electrocoagulation method. and to investigate the kinetic and adsorption isotherm studies on the removal efficiency.

\section{Experimental}

\section{Chemicals}

For all electrocoagulation experiments, a commercial formulation of the herbicide oxyfluorfen from Dow AgroSciences, USA, was used. The properties of the oxyfluorfen is given in Table 1. Mineral salts was routinely used for all electrocoagulation experiments. Sodium chloride, potassium chloride, sodium carbonate, sodium fluoride, sodium sulfate, sodium hydroxide, sulfuric acid, potassium dichromate, were of analytical grade and purchased from Merck. Distilled water was used for the preparation of solutions. Standard solutions of potassium dichromate $\left(\mathrm{K}_{2} \mathrm{Cr}_{2} \mathrm{O}_{7}\right)$, sulfuric acid $\left(\mathrm{H}_{2} \mathrm{SO}_{4}\right)$ reagent with silver sulfate $\left(\mathrm{Ag}_{2} \mathrm{SO}_{4}\right)$, Mercury sulfate $\left(\mathrm{HgSO}_{4}\right)$ and sulfuric acid $\left(\mathrm{H}_{2} \mathrm{SO}_{4}\right)$ were prepared to measure the COD. A stock solution of herbicide (1000 mg.L $\left.{ }^{1}\right)$ was prepared by dissolving an accurate quantity of the herbicide in distilled water and suitably diluted to the required initial concentrations. Different standard solutions of herbicide with concentration from 50 $250 \mathrm{mg} . \mathrm{L}^{-1}$ were prepared to measure its removal at different conditions.

\section{Electrolysis and analytical method}

The solution volume of $100 \mathrm{~mL}$ was used for each experiment as the electrolyte. The $\mathrm{pH}$ of the electrolyte was adjusted, if required, with $\mathrm{HCl}$ or $\mathrm{NaOH}$ (Merck, Darmstadt, Germany) solutions and measured by a $\mathrm{pH}$ meter (AC28-TOA electronics Ltd, Japan) at the beginning and during the experiment. After adjusting the initial solution $\mathrm{pH}$ to the desired value, the current density was set. Magnetic stirring at $250 \mathrm{rpm}$ provided a homogeneous solution in the batch reactor intervals, samples were taken for analysis. Temperature studies were carried at varying temperature $\left(10-50^{\circ} \mathrm{C}\right)$ to determine the type of reaction. The chemical oxygen demand (COD) was analyzed using UV-Vis Spectrophotometer (model UV 1601 is from Shimadzu, Japan).

\section{Experimental device}

Electrocoagulation is an electrochemical separation process that uses a direct current between pairs of metal sheets called electrodes. Metal electrodes immersed in solution, coagulant agents that destabilize pollutants [16] (Figure 1).

The experiments were carried out in reactor using $100 \mathrm{ml}$ Plexiglas vessel that was fitted cell cover with slots to introduce the electrodes, $\mathrm{pH}$ sensor, a thermometer and the electrolytes. Iron, stainless steel and aluminum of surface area $\left(4 \mathrm{~cm}^{2}\right)$ acted as the anode. The cathode was iron, stainless steel and aluminum sheets of the same size as the anode is placed at an inter-electrode distance of $1 \mathrm{~cm}$.

*Corresponding author: Nasser M Ghalwa, Department of Chemistry, Faculty of Science, Al-Azhar University-Gaza, Gaza Strip, Palestine, Tel: 970082641884 E-mail: dr.nasser.galwa@hotmail.com

Received March 14, 2017; Accepted March 21, 2017; Published April 02, 2017

Citation: Ghalwa NM, Musabeh AZ, Farhat NB (2017) Performance Efficiency of Electrocoagulation Adsorption Process of Oxyfluorfen Herbicide from Aqueous Solutions Using Different Anodes. J Environ Anal Toxicol 7: 448. doi: 10.4172/21610525.1000448

Copyright: @ 2017 Ghalwa NM, et al. This is an open-access article distributed under the terms of the Creative Commons Attribution License, which permits unrestricted use, distribution, and reproduction in any medium, provided the original author and source are credited. 
Citation: Ghalwa NM, Musabeh AZ, Farhat NB (2017) Performance Efficiency of Electrocoagulation Adsorption Process of Oxyfluorfen Herbicide from Aqueous Solutions Using Different Anodes. J Environ Anal Toxicol 7: 448. doi: 10.4172/2161-0525.1000448

Page 2 of 12

\begin{tabular}{|c|c|}
\hline Chemical structure & \\
\hline Commercial Name & Goal \\
\hline UV/VIS absorption (max.) & $\begin{array}{l}\text { neutral: } 275 \mathrm{~nm}, 320 \mathrm{~nm} \\
\text { acidic: } 273 \mathrm{~nm}, 320 \mathrm{~nm} \\
\text { basic: } 273 \mathrm{~nm}, 320 \mathrm{~nm}\end{array}$ \\
\hline Chemical formula & $\mathrm{C}_{15} \mathrm{H}_{11} \mathrm{ClF}_{3} \mathrm{NO}_{4}$ \\
\hline Molecular Weight (g/mol) & $361.70 \mathrm{~g} \cdot \mathrm{mol}^{-1}$ \\
\hline Form & $\begin{array}{l}\text { Solid at room temperature(pure } \\
\text { compound) }\end{array}$ \\
\hline IUPAC Name & $\begin{array}{c}\text { 2-chloro-1-(3-ethoxy-4-nitrophenoxy)- } \\
\text { 4-trifluoromethyl)benzene }\end{array}$ \\
\hline $\begin{array}{l}\text { Solubility in water (state temperature, } \\
\text { state purity and } \mathrm{pH} \text { ) }\end{array}$ & $0.116 \mathrm{mg} / \mathrm{L}\left(\right.$ at $\left.25^{\circ} \mathrm{C}, 99.1 \%\right)$ \\
\hline Hydrolysis half-life & half-life of 3.9 days $\left(20^{\circ} \mathrm{C}, \mathrm{pH} 5-9\right)$ \\
\hline Appearance & Yellow to brown \\
\hline n-octanol/water $\left(\log P_{\text {ow }}\right)$ & 4.7 \\
\hline $\begin{array}{l}\text { Partition coefficient, soil organic } \\
\text { carbon/water }\left(K_{o c}\right)\end{array}$ & $6.831 \mathrm{~cm}^{3} \cdot \mathrm{g}^{-1}$ \\
\hline Vapor pressure & $2 \times 10^{-7} \mathrm{mmHg}$ at $25^{\circ} \mathrm{C}$ \\
\hline
\end{tabular}

Table 1: Chemical - Physical Properties of oxyfluorfen.

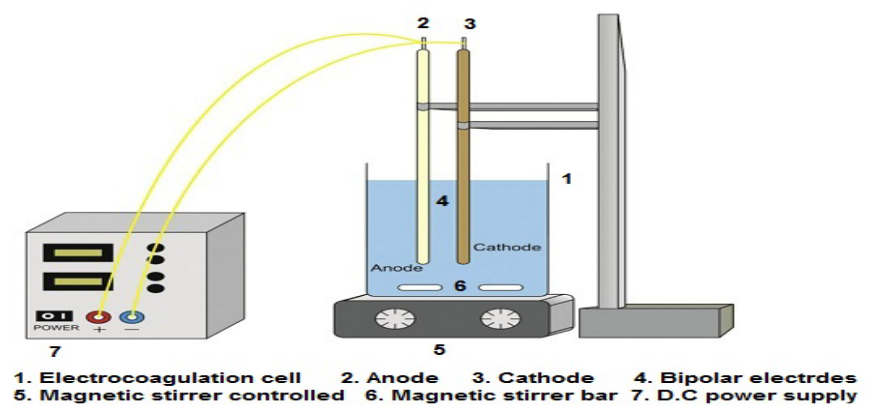

Figure 1: Bench-scale EC reactor with bipolar electrodes in parallel connection. (1) Electrocoagulation cell; (2) Anode; (3) Cathode; (4) bipolar electrodes; (5) Magnetic stirrer controlled; (6) Magnetic stirrer bar; (7) D.C. power supply.

\section{Analysis}

The remaining pollutants of oxyfluorfen concentration was measured with the double-beam UV-Vis spectrophotometer at $\lambda \max =320 \mathrm{~nm}$. The COD was determined using a closed reflux colorimetric method [17].

The equation used to determine the herbicide adsorption in the treatment experiments was:

$$
\% \mathrm{E}=\left[\left(\mathrm{A}_{\mathrm{o}}-\mathrm{A}\right) / \mathrm{A}_{\mathrm{o}}\right] \times 100
$$

Where $\mathrm{A}_{0}$ and $\mathrm{A}$ are absorbance values of herbicides solutions before and after adsorption.

The calculation of COD removal efficiencies after electrocoagulation treatment were performed using the following formula [18].

$$
\mathrm{C}_{\mathrm{R}}(\%)=\left[\left(\mathrm{C}_{\mathrm{o}}-\mathrm{C}\right) / \mathrm{C}_{\mathrm{o}}\right] \times 100
$$

Where $\mathrm{C}_{\mathrm{o}}$ and $\mathrm{C}$ are concentrations of herbicides before and after electrocoagulation.

\section{Mechanism of electrocoagulation process}

The mechanisms of the removal of herbicides by EC will be explained with two specific examples involving iron and aluminum since these two metals have been extensively used to clarify pollutant water [19]. Following each run, the electrodes were put in $\mathrm{HCl}(5 \% \mathrm{~V} / \mathrm{V})$ and rinsed with tap water then distilled water and dried until they are used again. Electrocoagulation of herbicide solution using iron $(\mathrm{Fe})$, stainless steel (S-S) and aluminum (Al) electrodes takes place according to the following mechanisms [20].

\section{Iron electrodes}

\section{Mechanism 1}

Anode:

$$
\begin{aligned}
& 4 \mathrm{Fe}_{(\mathrm{s})} \rightarrow 4 \mathrm{Fe}^{2+}{ }_{\text {(aq) }}+8 \mathrm{e}^{-} \\
& 4 \mathrm{Fe}^{2+}{ }_{(\text {aq })}+10 \mathrm{H}_{2} \mathrm{O}_{(\mathrm{l})}+\mathrm{O}_{2(\mathrm{aq})} \rightarrow 4 \mathrm{Fe}(\mathrm{OH})_{3(\mathrm{~s})}+8 \mathrm{H}^{+}{ }_{(\mathrm{aq})}
\end{aligned}
$$

\section{Cathode:}

$8 \mathrm{H}^{+}{ }_{(\mathrm{aq})}+8 \mathrm{e}^{-} \rightarrow 4 \mathrm{H}_{2(\mathrm{~g})}$

Overall:

$4 \mathrm{Fe}_{(\mathrm{s})}+10 \mathrm{H}_{2} \mathrm{O}_{(\mathrm{l})}+\mathrm{O}_{2(\mathrm{aq})} \rightarrow 4 \mathrm{Fe}(\mathrm{OH})_{3(\mathrm{~s})}+4 \mathrm{H}_{2(\mathrm{~g})}$

\section{Mechanism 2}

Anode:

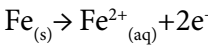

$\mathrm{Fe}^{2+}{ }_{(\mathrm{aq})}+2 \mathrm{OH}^{-}{ }_{(\mathrm{aq})} \rightarrow \mathrm{Fe}(\mathrm{OH})_{2(\mathrm{~s})}$

Cathode :

$$
2 \mathrm{H}_{2} \mathrm{O}_{(\mathrm{l})}+2 \mathrm{e}^{-} \rightarrow \mathrm{H}_{2(\mathrm{~g})}+2 \mathrm{OH}^{-}{ }_{(\text {aq })}
$$

Overall:

$$
\mathrm{Fe}_{(\mathrm{s})}+2 \mathrm{H}_{2} \mathrm{O}_{(\mathrm{l})} \rightarrow \mathrm{Fe}(\mathrm{OH})_{2(\mathrm{~s})}+\mathrm{H}_{2(\mathrm{~g})}
$$

\section{Aluminum electrodes}

$$
\begin{aligned}
& \text { Anode: } \mathrm{Al}_{(\mathrm{s})} \rightarrow \mathrm{Al}_{(\mathrm{aq})}^{3+}+3 \mathrm{e}^{-} \\
& \text {Cathode: } 3 \mathrm{H}_{2} \mathrm{O}_{(\mathrm{l})}+3 \mathrm{e}^{-} \rightarrow 3 / 2 \mathrm{H}_{2}+3 \mathrm{OH}^{-} \\
& \text {Overall: } \mathrm{Al}_{(\mathrm{s})}+3 \mathrm{H}_{2} \mathrm{O}_{(\mathrm{l})} \rightarrow \mathrm{Al}(\mathrm{OH})_{3(\mathrm{~s})}
\end{aligned}
$$

\section{Result and Discussion}

The adsorption of oxyfluorfen was examined by EC using Fe, S-S and $\mathrm{Al}$ electrodes. The effects of current density, initial $\mathrm{pH}$, type of electrolyte, $\mathrm{NaCl}$ concentration, initial herbicides concentration, temperature and Effect of anode materials were investigated on oxyfluorfen and COD removal efficiency. The main parameters discussed from this work are:

\section{Effect of current density $\left(\mathrm{mA} . \mathrm{cm}^{-2}\right)$}

The effect of current density on the oxyfluorfen and COD removal efficiency a series of experiments were carried out at time $30 \mathrm{~min}, \mathrm{pH}$ 5.8 , oxyfluorfen $200 \mathrm{mg} . \mathrm{L}^{-1}, \mathrm{NaCl} 1 \mathrm{~g} . \mathrm{L}^{-1}$, inter-electrode distance $1 \mathrm{~cm}$ and temperature $10^{\circ} \mathrm{C}$. Figure 2 show the effect of current densities for oxyfluorfen and COD removal efficiencies increased by increasing the current density up to (95\% and $84 \%),(99 \%$ and $85 \%)$ and (96\% and $70 \%)$ at $\mathrm{Fe}, \mathrm{S}-\mathrm{S}$ and $\mathrm{Al}$ electrodes respectively. The increase of coagulant and bubbles generation rate lead to the increase number of $\mathrm{H}_{2}$ bubbles and decrease their size with increasing current density resulting in a faster removal of herbicides [21]. The sufficient amount of flocs needed to coagulate the herbicide might be available at optimal current density and further formation of flocs which did not change herbicide and COD removal efficiency [22]. 
Citation: Ghalwa NM, Musabeh AZ, Farhat NB (2017) Performance Efficiency of Electrocoagulation Adsorption Process of Oxyfluorfen Herbicide from Aqueous Solutions Using Different Anodes. J Environ Anal Toxicol 7: 448. doi: 10.4172/2161-0525.1000448
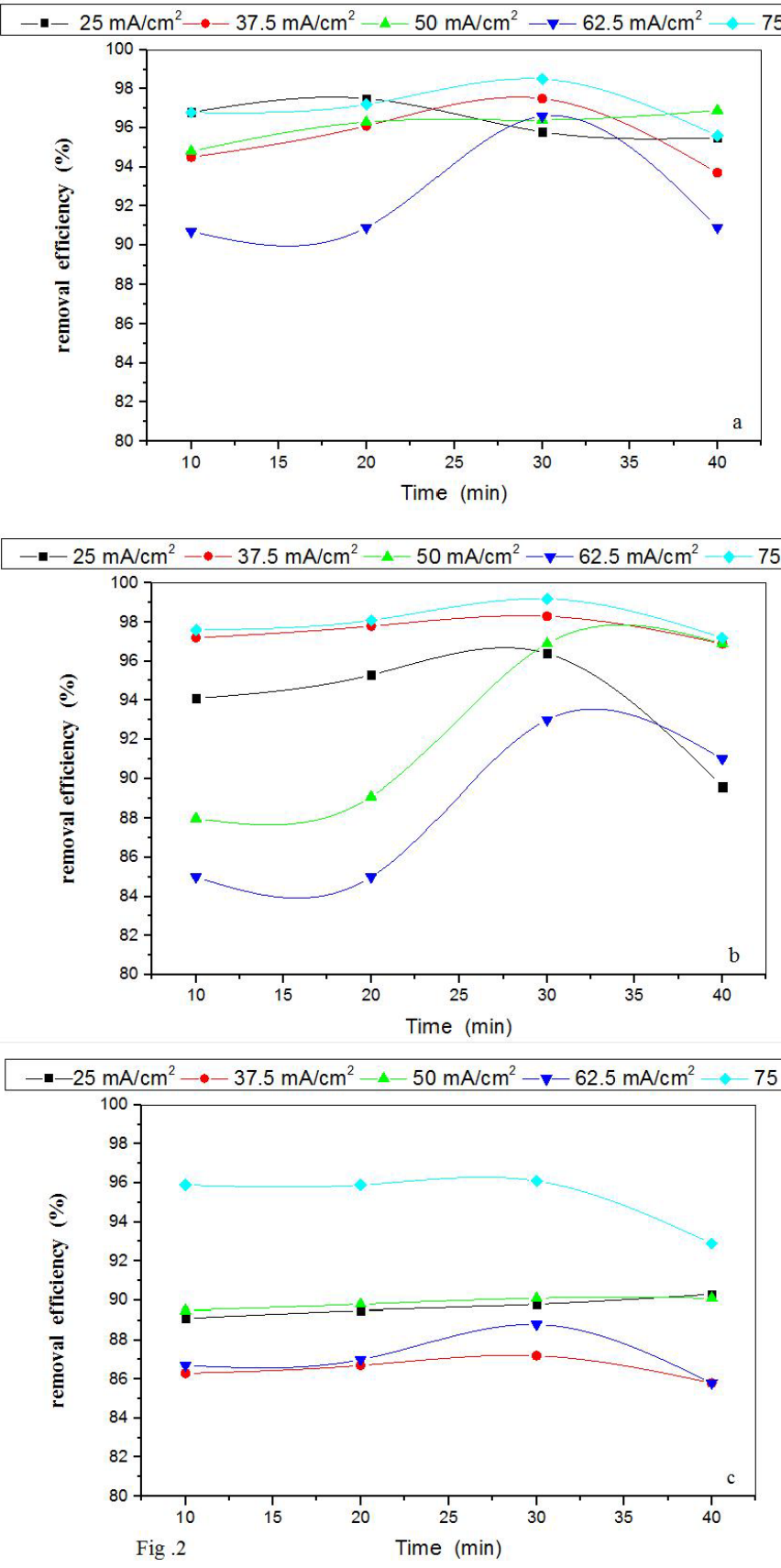
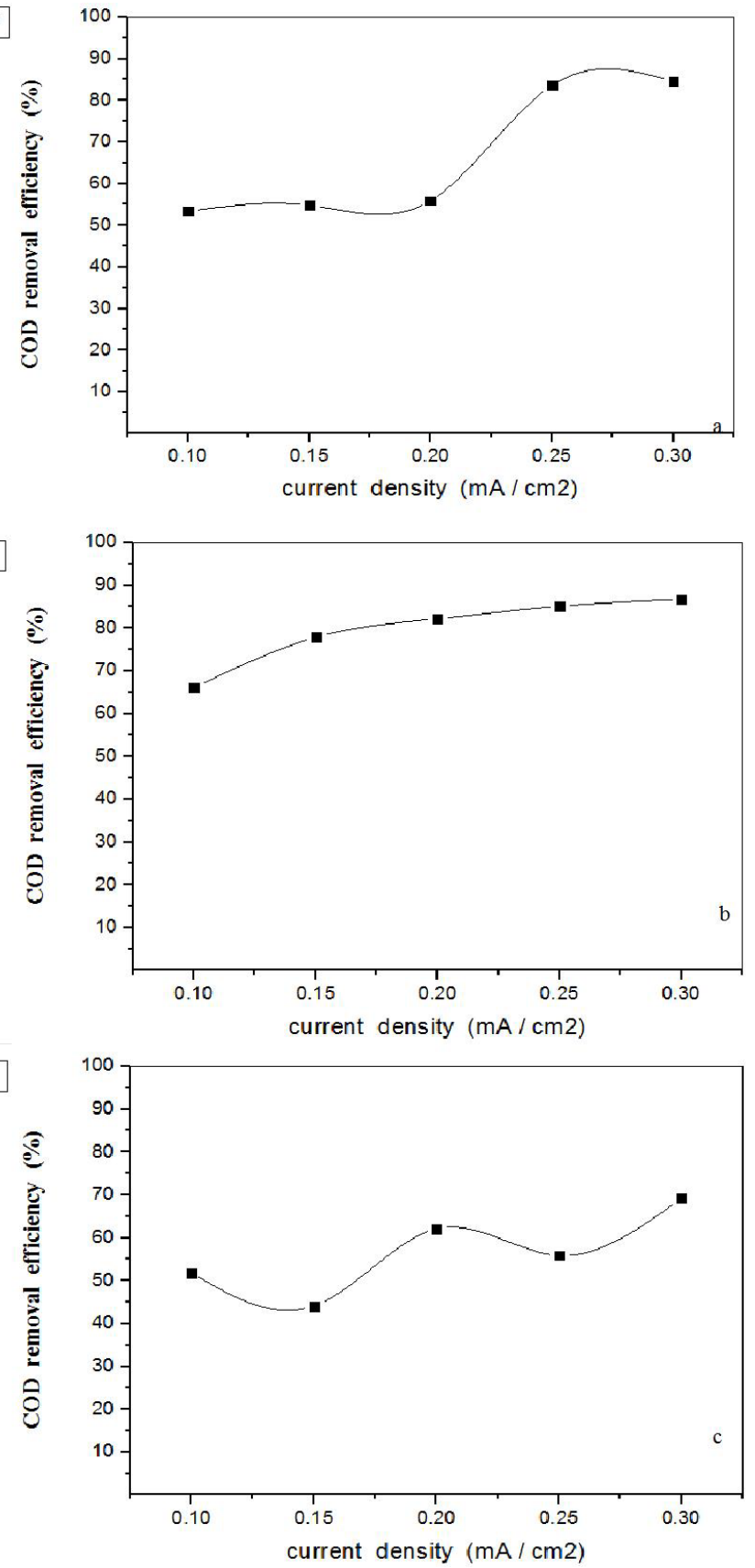

Figure 2: Effect of current density and COD on the removal efficiency of oxyfluorfen using Fe (a) S-S (b) and Al (c) electrodes. Initial concentration of the oxyfluorfen=200 $\mathrm{mg} / \mathrm{L},[\mathrm{NaCl}]=1 \mathrm{~g} / \mathrm{L}, \mathrm{pH}=5.8$, inter-electrode distance $=1 \mathrm{~cm}$, temperature $=10^{\circ} \mathrm{C}$.

\section{Effect of initial pH}

$\mathrm{pH}$ is an important operating factor influencing the performance of the electrocoagulation process. A series of experiments was carried out to evaluate this effect, using solutions containing a sample with an initial $\mathrm{pH}$ varying in the range (2-10) at time $30 \mathrm{~min}$, oxyfluorfen $200 \mathrm{mg} . \mathrm{L}^{-1}$, current density $75 \mathrm{~mA} . \mathrm{cm}^{-2}, \mathrm{NaCl} 1$ g. $\mathrm{L}^{-1}$, and temperature $10^{\circ} \mathrm{C}$. From Figure 3 it can be seen that the removal efficiency of oxyfluorfen was increased by increasing the $\mathrm{pH}$ and the maximum removal efficiency was obtained in neutral and slightly alkaline medium.

\section{Effect of type of electrolyte}

Figure 4 show the effect of electrolyte type on the removal efficiency of oxyfluorfen and COD at $30 \mathrm{~min}$ using different anodes in the presence of different supporting electrolytes including $\left(\mathrm{KCl}, \mathrm{Na}_{2} \mathrm{CO}_{3}, \mathrm{NaF}\right.$ and $\mathrm{Na}_{2} \mathrm{SO}_{4}$ ) at time $30 \mathrm{~min}$. It can be seen from Figure 4 that in the presence of chloride ions for $\mathrm{NaCl}$ and $\mathrm{KCl}$ electrolytes the removal efficiency of herbicides and COD were high due to formation of hypochlorite $(\mathrm{OCl}$ ) and hypochlorous acid ( $\mathrm{HOCl})$. But in another electrolytes which not contain chloride ions such as $\mathrm{Na}_{2} \mathrm{CO}_{3}$ and $\mathrm{Na}_{2} \mathrm{SO}_{4}$, the removal 
Citation: Ghalwa NM, Musabeh AZ, Farhat NB (2017) Performance Efficiency of Electrocoagulation Adsorption Process of Oxyfluorfen Herbicide from Aqueous Solutions Using Different Anodes. J Environ Anal Toxicol 7: 448. doi: 10.4172/2161-0525.1000448
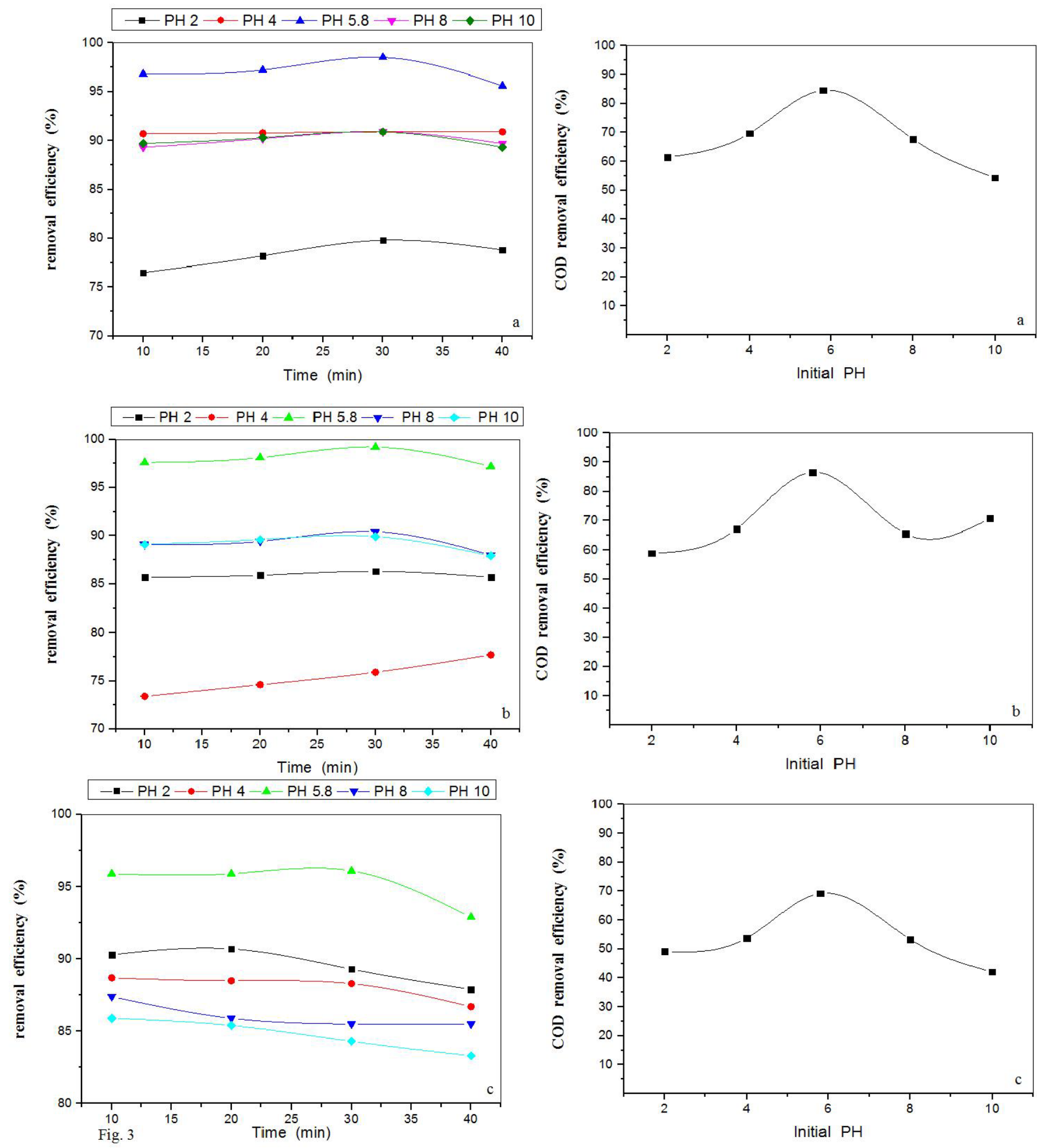

Figure 3: Effect of initial $\mathrm{pH}$ and COD on the removal efficiency of oxyfluorfen using Fe (a) S-S (b) and Al (c) electrodes. Initial concentration of the oxyfluorfen=200 $\mathrm{mg} / \mathrm{L},[\mathrm{NaCl}]=1 \mathrm{~g} / \mathrm{L}$, current density $=75 \mathrm{~mA} / \mathrm{cm}^{2}$, inter-electrode distance $=1 \mathrm{~cm}$, temperature $=10^{\circ} \mathrm{C}$.

efficiency of herbicides and COD dropped. This may be attributed to the formation of an adherent film on the anode surface which poisons the electrode surface [23].

\section{Effect of electrolyte concentration (g.L $\left.\mathrm{L}^{-1}\right)$}

The conductivity of the water is adjusted to the desired values by adding $\mathrm{NaCl}$ [24]. Figure 5 represent the effect of electrolyte 
Citation: Ghalwa NM, Musabeh AZ, Farhat NB (2017) Performance Efficiency of Electrocoagulation Adsorption Process of Oxyfluorfen Herbicide from Aqueous Solutions Using Different Anodes. J Environ Anal Toxicol 7: 448. doi: 10.4172/2161-0525.1000448
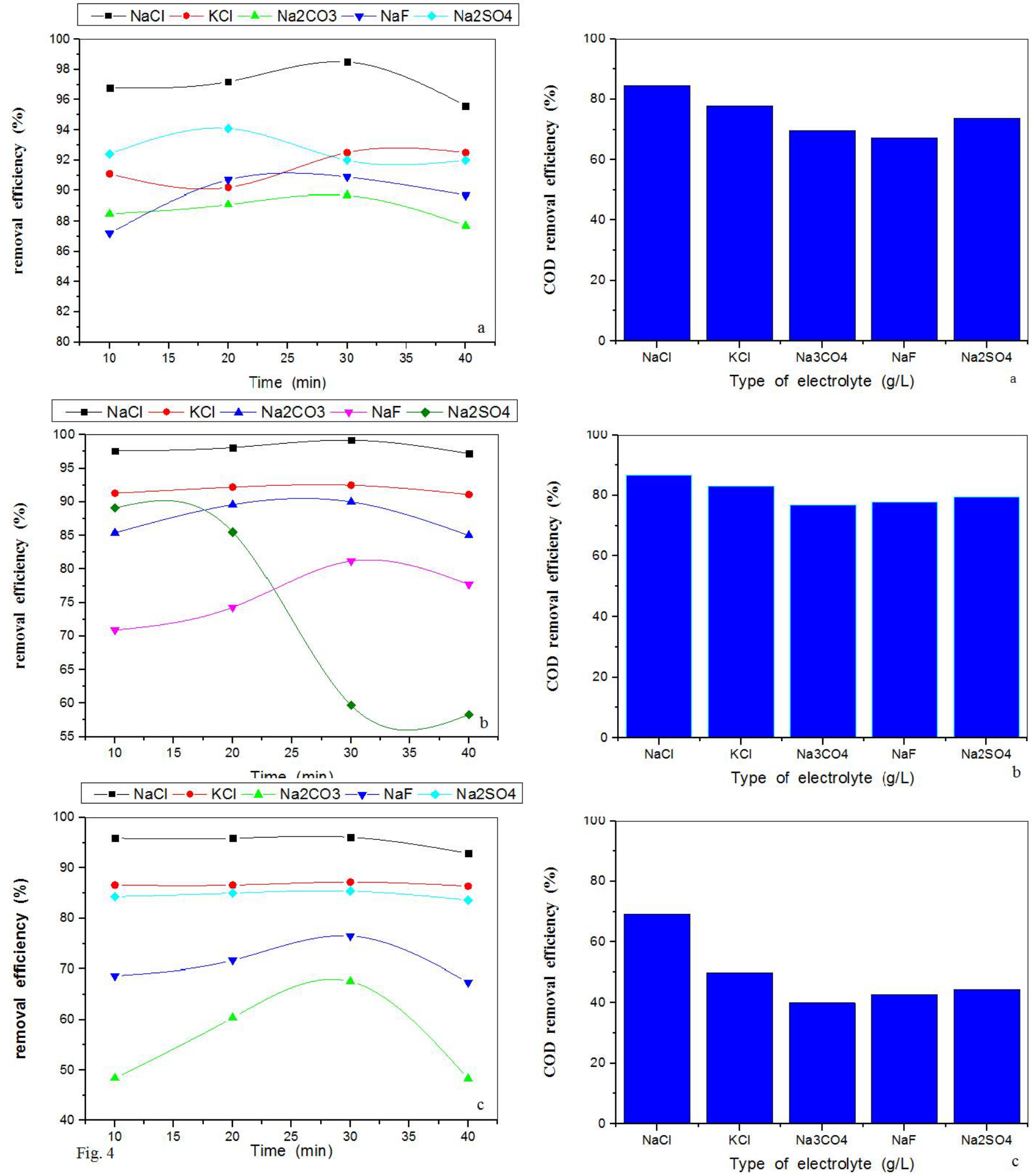

Figure 4: Effect of electrolyte and COD on the removal efficiency of oxyfluorfen using Fe (a) S-S (b) and Al (c) electrodes. Initial concentration of the oxyfluorfen=200 $\mathrm{mg} / \mathrm{L}$, [electrolyte] $=1 \mathrm{~g} / \mathrm{L}, \mathrm{pH}=5.8$, current density $=75 \mathrm{~mA} / \mathrm{cm}^{2}$, interelectrode distance $=1 \mathrm{~cm}$, temperature $=10^{\circ} \mathrm{C}$.

concentrations on oxyfluorfen and COD removal efficiencies at time 30 min. pH 5.8, oxyfluorfen 200 mg.L $\mathrm{L}^{-1}, 75 \mathrm{~mA} . \mathrm{cm}^{-2}$, inter-electrode distance $1 \mathrm{~cm}$ and temperature $10^{\circ} \mathrm{C}$. The results obtained from the above figures indicate that $1 \mathrm{~g} . \mathrm{L}^{-1} \mathrm{NaCl}$ was the maximum value 
Citation: Ghalwa NM, Musabeh AZ, Farhat NB (2017) Performance Efficiency of Electrocoagulation Adsorption Process of Oxyfluorfen Herbicide from Aqueous Solutions Using Different Anodes. J Environ Anal Toxicol 7: 448. doi: 10.4172/2161-0525.1000448
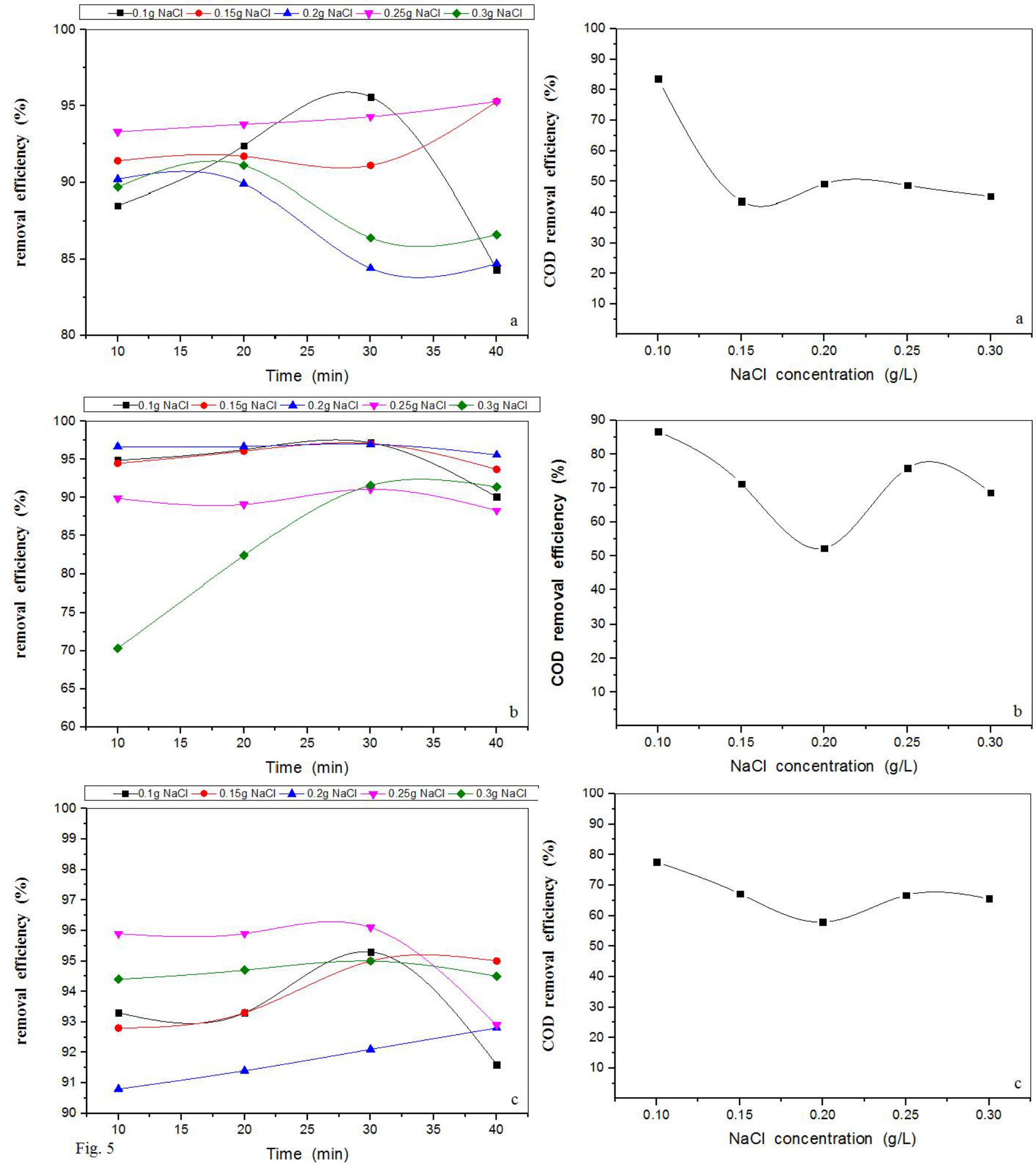

Figure 5: Effect of electrolyte concentration and COD on the removal efficiency of oxyfluorfen using Fe (a) S-S (b) and Al (c) electrodes. Initial concentration of the oxyfluorfen $=200 \mathrm{mg} / \mathrm{L}, \mathrm{pH}=5.8$, current density $=75 \mathrm{~mA} / \mathrm{cm}^{2}$, interelectrode distance $=1 \mathrm{~cm}$, temperature $=10^{\circ} \mathrm{C}$.

for removal efficiencies. It can be attributed that the increase of the conductivity by the addition of sodium chloride is known to reduce the cell voltage at constant current density due to the decrease of the ohmic resistance of solution $[25,26]$. 
Citation: Ghalwa NM, Musabeh AZ, Farhat NB (2017) Performance Efficiency of Electrocoagulation Adsorption Process of Oxyfluorfen Herbicide from Aqueous Solutions Using Different Anodes. J Environ Anal Toxicol 7: 448. doi: 10.4172/2161-0525.1000448

Page 7 of 12

\section{Effect of initial oxyfluorfen concentration $\left(\mathrm{mg} . \mathrm{L}^{-1}\right)$}

To observe the effect of initial herbicide concentration on oxyfluorfen and COD on the removal efficiencies by EC, experiments were carried out for five different oxyfluorfen concentration (50-250 mg. $\mathrm{L}^{-1}$ ) for $30 \mathrm{~min}$, pH 5.8, $\mathrm{NaCl} 1$ g.L $\mathrm{L}^{-1}$, current density $75 \mathrm{mAcm}^{-2}$, inter-electrode distance $1 \mathrm{~cm}$ and temperature $10^{\circ} \mathrm{C}$. Figure 6 show the percentage removal efficiencies of oxyfluorfen and COD for different initial oxyfluorfen concentration. The maximum removal was obtained at herbicide concentration $100 \mathrm{mg} \mathrm{L}^{-1}$. Further increasing of the initial concentration leads to decrease in the herbicides removal efficiency. Because the amount of hydroxyl and metal ions produced on the electrodes was not sufficient to adsorb at high oxyfluorfen concentrations at a constant current density [27].

\section{Effect of temperature $\left({ }^{\circ} \mathrm{C}\right)$}

Figure 7 show the effect of temperature on oxyfluorfen and COD removal efficiencies at $30 \mathrm{~min}$., initial concentration of the oxyfluorfen $=200 \mathrm{mg} / \mathrm{L}, \quad[\mathrm{NaCl}]=1 \mathrm{~g} / \mathrm{L}, \quad \mathrm{pH}=5.8$, Inter-electrode distance $=1 \mathrm{~cm}$ and temperature $=10^{\circ} \mathrm{C}$. Increasing temperature has a negative effect on both removal efficiency of herbicides and COD values, where the optimal temperature for oxyfluorfen were $10^{\circ} \mathrm{C}$ using all electrodes. While at higher temperature value the herbicide and COD removal dropped to low values. It may be concluded that at low temperature the dissolution of anode occurs at a lower rate. When the temperature was over $10^{\circ} \mathrm{C}$, the removal efficiency began to decrease. In this case, the volume of colloid $\mathrm{M}(\mathrm{OH})_{n}$ will decrease and pore production on the metal anode well be closed [28].

\section{Effect of anode materials}

Effect of different anode materials on the removal efficiency of oxyfluorfen was evaluated using iron, stainless steel and aluminum anodes. Due to the effective adsorption nature, the contaminants in the water will be removed by the adsorption with metal hydroxides produced from the chemical coagulants [29]. A contaminant free ion source allows maximum adsorptive removal of the various dissolved forms of metals that could be present and require treatment. During the electrolysis of anodes like $\mathrm{Fe} / \mathrm{S}-\mathrm{S} / \mathrm{Al}$, respective hydroxides (microflocs) are formed rapidly by anodic dissolution according to reactions (3)(13). The main advantage in the case of Fe and S-S electrode is that the residual iron if any present in treated water will not cause any health problem like aluminum.

\section{Kinetic studies of oxyfluorfen}

Rate of reaction describes the rates of change in concentration of reactant per unit time [30]. Figure 8 represent the oxyfluorfen removal using EC method of which exhibited pseudo first order with good correlation coefficient $0.9528,0.9547$ and 0.9618 using $\mathrm{Fe}, \mathrm{S}-\mathrm{S}$ and $\mathrm{Al}$ electrodes according to following equation:

$$
\mathrm{LnA}_{\mathrm{t}} / \mathrm{A}_{\mathrm{o}}=-\mathrm{Kt}
$$

Where Ao, At, $t$ and $k$ are the oxyfluorfen absorbance at initial time reaction, oxyfluorfen absorbance after reaction, time of reaction (min) and reaction rate constant $\left(\mathrm{min}^{-1}\right)$ respectively. The straight lines in plots show a good agreement of experimental data with the kinetic models for different removal rate. The calculated $\mathrm{k}$ values from the Figure 8 are $0.023,0.025$ and $0.012 \mathrm{~min}^{-1}$ using $\mathrm{Fe}, \mathrm{S}-\mathrm{S}$ and $\mathrm{Al}$ electrodes. As indicated from above figures, the efficiency removal rate of oxyfluorfen increase according the order $\mathrm{S}-\mathrm{S}>\mathrm{Fe}>\mathrm{Al}$.

\section{Analyses of adsorption data}

Isotherm modeling: In this study, two adsorption isotherms viz., Freundlich and Langmuir models were applied to establish the relationship between the amounts of oxyfluorfen adsorbed onto the Aluminum hydroxides and its equilibrium concentration in the electrolyte containing contaminant ions.

The Langmuir equation: The Langmuir isotherm is valid for monolayer adsorption onto a surface containing a finite number of identical sites. The model assumes uniform energies of adsorption onto the surface and no transmigration of adsorbate in the plane of the surface [31]. Based upon these assumptions, Langmuir represented the following equation:

$$
1 / q_{e}=1 / q_{m}+1 /\left(q_{m} K_{L} C_{e}\right)
$$

where qe (mg. $\left.\mathrm{g}^{-1}\right)$ is amount adsorbed at equilibrium, Ce (mg. $\left.\mathrm{L}^{-1}\right)$ equilibrium concentration, qm is the Langmuir constant representing maximum monolayer adsorption capacity and $\mathrm{KL}\left(\mathrm{L} \cdot \mathrm{mg}^{-1}\right)$ is the Langmuir constant related to energy of adsorption. The essential characteristics of the Langmuir isotherm can be expressed as the dimensionless constant $\mathrm{R}_{\mathrm{L}}$ [32].

$$
\mathrm{R}_{\mathrm{L}}=\mathbf{1} / \mathbf{1}+\left(\mathrm{K}_{\mathrm{L}}+\mathrm{C}_{\mathrm{o}}\right)
$$

Where $\mathrm{C}_{\mathrm{o}}$ is the initial concentration, $\mathrm{K}_{\mathrm{L}}$ the constant related to the energy of adsorption (Langmuir Constant). The $\mathrm{R}_{\mathrm{L}}$ values between 0 and 1 indicate the favorable adsorption.

Freundlich adsorption isotherm: This is commonly used to describe the adsorption characteristics for the heterogeneous surface [33]. The Freundlich adsorption isotherm typically fits the experimental data over a wide range of concentrations. These data often fit the empirical equation proposed by Freundlich:

\section{$\log q_{e}=\log K_{f}+1 / n \log C_{e}$}

where $\mathrm{kf}\left(\mathrm{mg}^{\mathrm{g}} \mathrm{g}^{-1}\right)$ and $\mathrm{n}$ (dimensionless) are constants that account for all factors affecting the adsorption process, such as the adsorption capacity and intensity. The Freundlich constants $K_{f}$ and $n$ are determined from the intercept and slope, respectively, of the linear plot of $\log \mathrm{q}_{\mathrm{e}}$ versus $\log \mathrm{C}_{\mathrm{e}}$

According the equation (15 and 17) the contaminants are usually adsorbed at the surface of the metal hydroxides generated during the electrocoagulation process. Figure 9 and Table 2 represent the Langmuir and Freundlich Isotherms studies of equilibrium.

\section{Operating cost}

Operating Cost One of the most important parameters that must be determined to evaluate a method of water treatment is the cost. The operating cost includes material (mainly electrodes) cost, operating cost (mainly electrical energy) In this study, energy and electrode material costs have been taken into account as major cost items [34].

Electrical energy consumption: In an electrochemical process, the most important economical parameter is energy consumption Ec $\left(\mathrm{KWh} / \mathrm{m}^{3}\right)$ [35]. This parameter is calculated from the following expression:

$$
E c=\frac{\text { V.I.t }}{\text { volume } 1000}
$$

Where $\mathrm{V}, \mathrm{I}, \mathrm{t}$ and Volume stand for average voltage of the EC system $(\mathrm{V})$, electrical current intensity $(\mathrm{A})$, reaction time $(\mathrm{h})$ and treated solution volume $\left(\mathrm{m}^{3}\right)$ respectively. 
Citation: Ghalwa NM, Musabeh AZ, Farhat NB (2017) Performance Efficiency of Electrocoagulation Adsorption Process of Oxyfluorfen Herbicide from Aqueous Solutions Using Different Anodes. J Environ Anal Toxicol 7: 448. doi: 10.4172/2161-0525.1000448
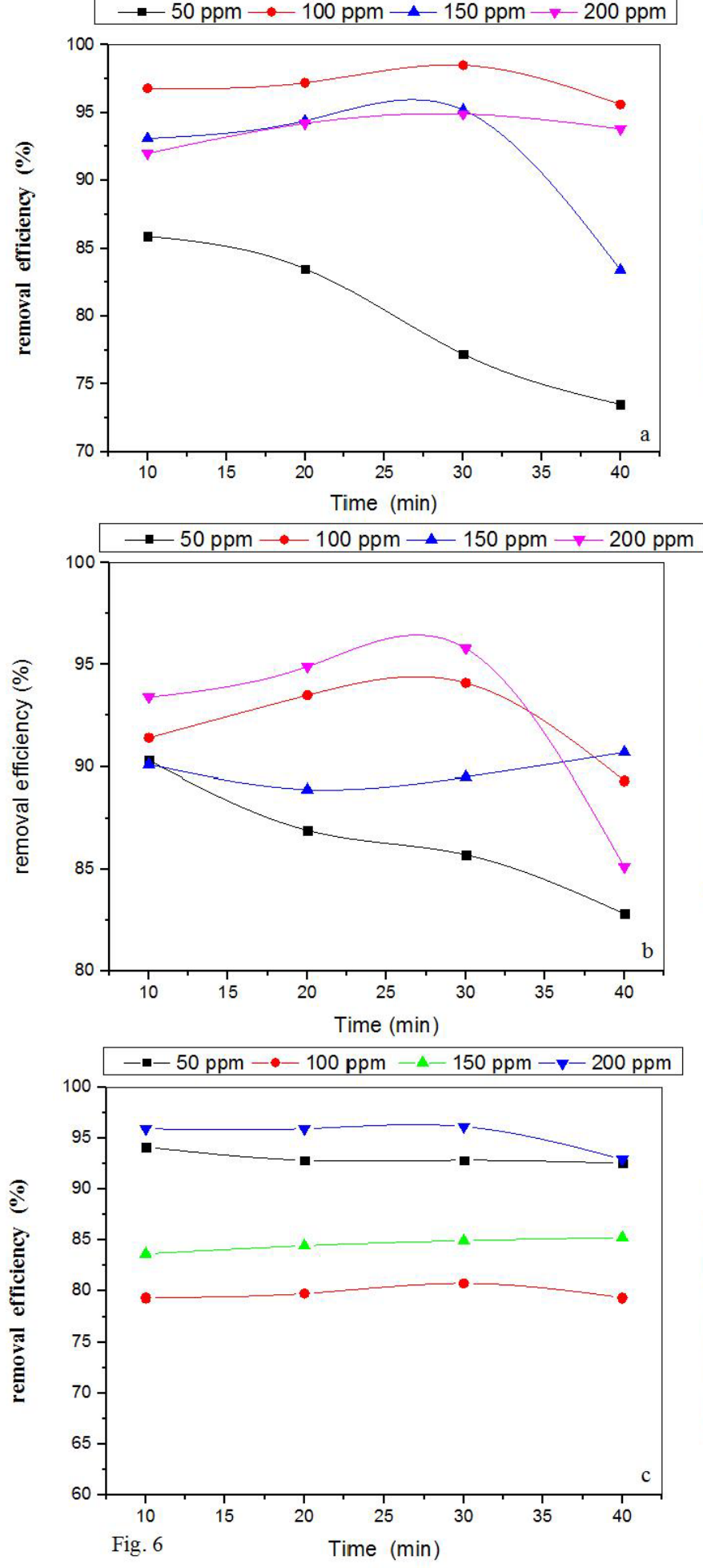
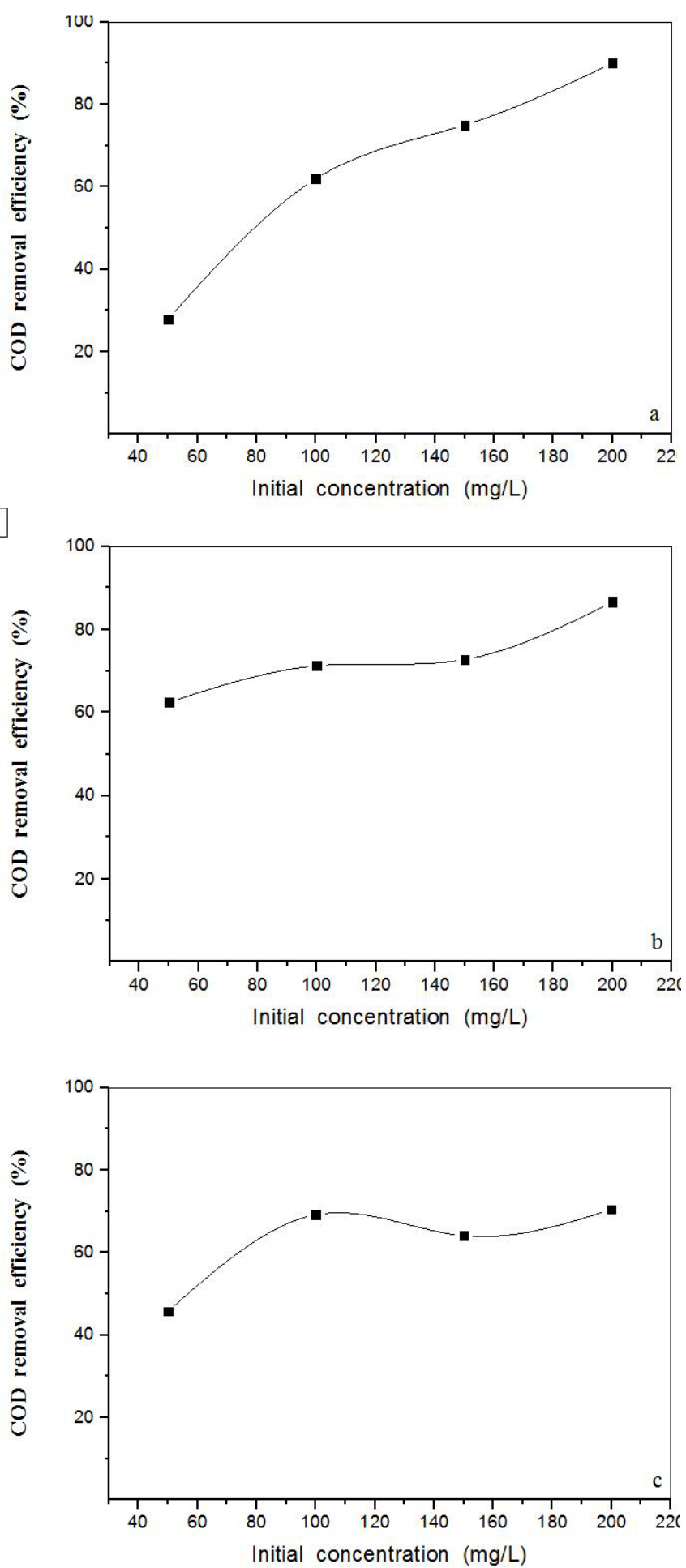

Figure 6: Effect of initial oxyfluorfen concentration and COD on the removal efficiency of oxyfluorfen using $\mathrm{Fe}(\mathrm{a}) \mathrm{S}-\mathrm{S}(\mathrm{b})$ and $\mathrm{Al}(\mathrm{c}) \mathrm{electrodes}$. [NaCl]=1 g/L, pH=5.8, a current density $=75 \mathrm{~mA} / \mathrm{cm}^{2}$, inter-electrode distance $=1 \mathrm{~cm}$, temperature $=10^{\circ} \mathrm{C}$.

According the equation (18), The electrical energy consumption for oxyfluorfen electrocoagulation were $\left(7.95 \times 10^{-3}, 8.325 \times 10^{-3}\right.$ and 7.05 $\times 10^{-3} \mathrm{KWh} / \mathrm{m}^{3}$ ) using Fe, S-S and $\mathrm{Al}$ electrodes respectively according the equation (18) at current density of $0.3 \mathrm{~A}$ and cell voltage (10.6, 11.1 and $9.4 \mathrm{~V})$. 
Citation: Ghalwa NM, Musabeh AZ, Farhat NB (2017) Performance Efficiency of Electrocoagulation Adsorption Process of Oxyfluorfen Herbicide from Aqueous Solutions Using Different Anodes. J Environ Anal Toxicol 7: 448. doi: 10.4172/2161-0525.1000448
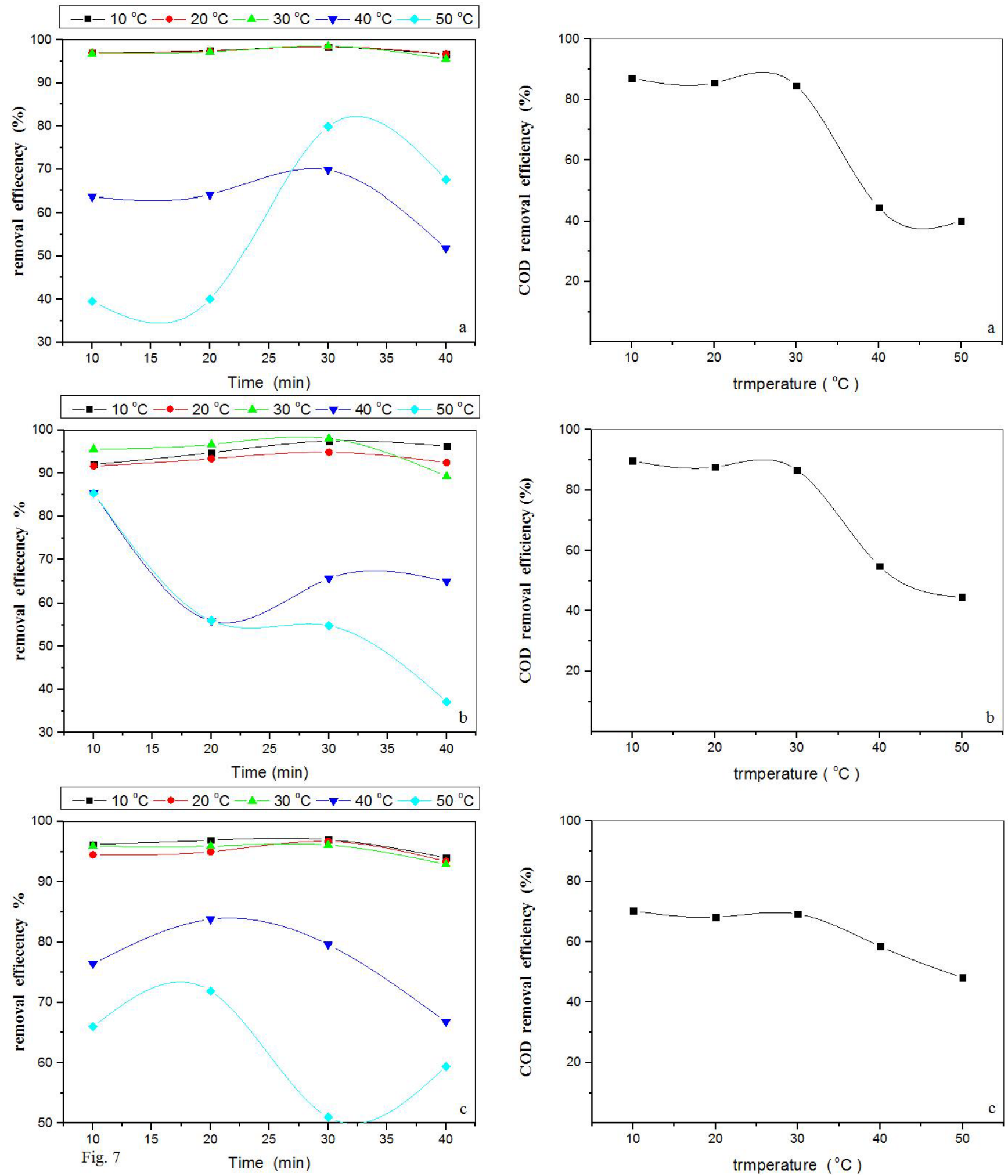

Figure 7: Effect of temperature and COD on the removal efficiency of oxyfluorfen using Fe (a) S-S (b) and Al (c) electrodes. Initial concentration of the oxyfluorfen=200 $\mathrm{mg} / \mathrm{L},[\mathrm{NaCl}]=1 \mathrm{~g} / \mathrm{L}, \mathrm{pH}=5.8$, a current density $=75 \mathrm{~mA} / \mathrm{cm}^{2}$, interelectrode distance $=1 \mathrm{~cm}$.

\section{Mass of loss from anode electrode}

The maximum possible mass of $\mathrm{Fe}$ and $\mathrm{Al}$ electrochemically generated from sacrificial anodes for a particular electrical current was calculated using Faraday's law of electrolysis [36]: 
Citation: Ghalwa NM, Musabeh AZ, Farhat NB (2017) Performance Efficiency of Electrocoagulation Adsorption Process of Oxyfluorfen Herbicide from Aqueous Solutions Using Different Anodes. J Environ Anal Toxicol 7: 448. doi: 10.4172/2161-0525.1000448
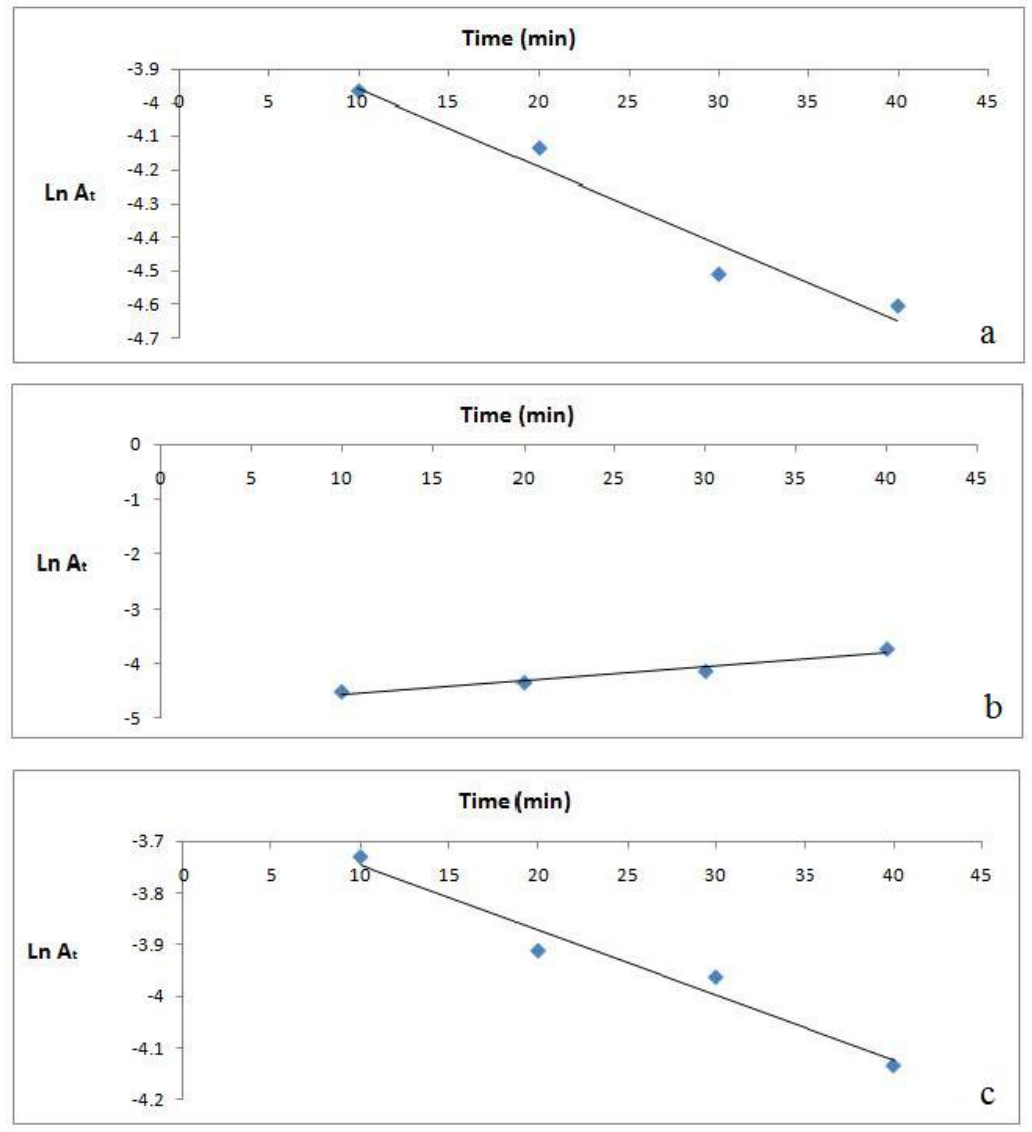

Figure 8: Reaction between $\mathrm{LnA}$ against the time for oxyfluorfen removal using Fe (a) S-S (b) and Al (c) electrodes. initial concentration of the oxyfluorfen=200 mg/L, $[\mathrm{NaCl}]=1 \mathrm{~g} / \mathrm{L}, \mathrm{pH}=5.8$, a current density $=75 \mathrm{~mA} / \mathrm{cm}^{2}$, inter-electrode distance $=1 \mathrm{~cm}$, temperature $=10^{\circ} \mathrm{C}$.

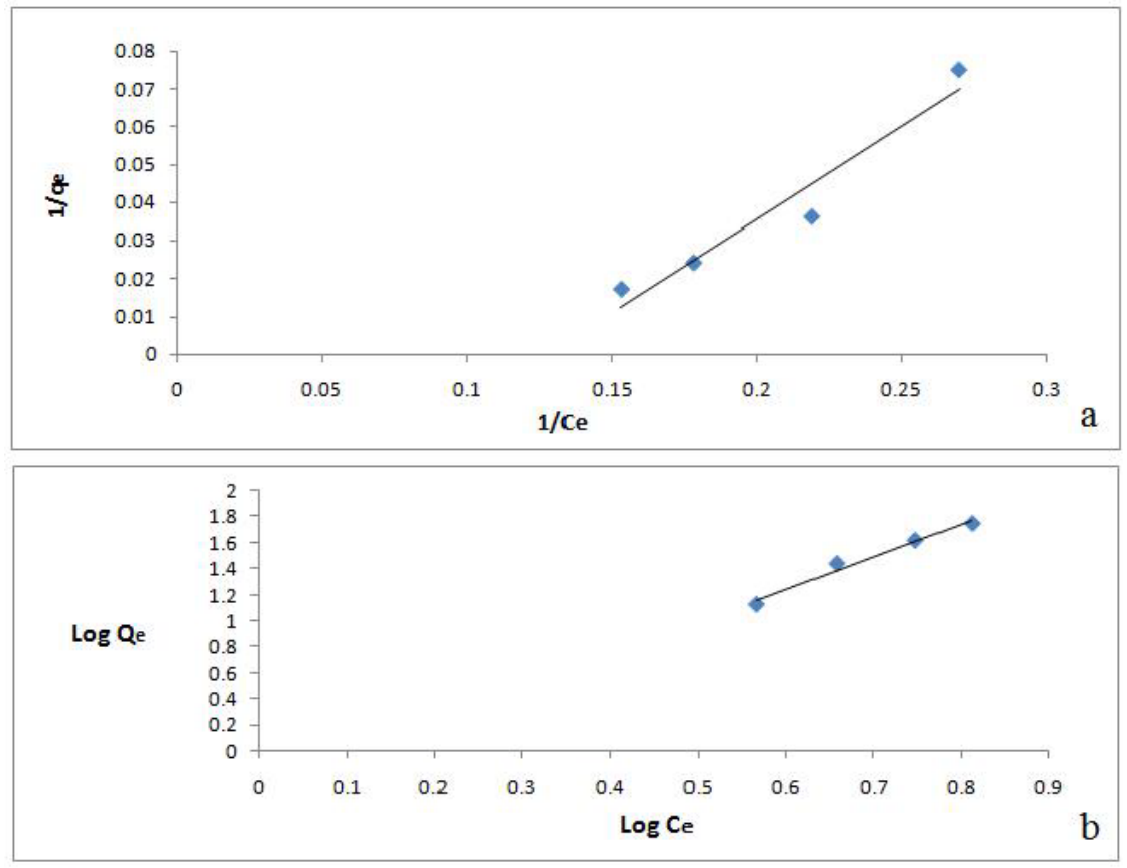

Figure 9: Langmuir adsorption Isotherm, (b) Freundlich adsorption Isotherm. 
Citation: Ghalwa NM, Musabeh AZ, Farhat NB (2017) Performance Efficiency of Electrocoagulation Adsorption Process of Oxyfluorfen Herbicide from Aqueous Solutions Using Different Anodes. J Environ Anal Toxicol 7: 448. doi: 10.4172/2161-0525.1000448

\begin{tabular}{|c|c|c|c|c|c|c|}
\hline \multicolumn{3}{|c|}{ Langmuir Isotherm } & \multicolumn{3}{c|}{ Freundlich Isotherm } \\
\hline $\mathbf{q}_{\mathbf{m}}\left(\mathbf{m g} \mathbf{~ g}^{-1}\right)$ & $\mathbf{k}_{\mathbf{L}}\left(\mathbf{L} \mathbf{~ m g}^{-1}\right)$ & $\mathbf{R}_{\mathbf{L}}$ & $\mathbf{R}^{\mathbf{2}}$ & $\mathbf{k}_{\mathbf{f}}$ & $\mathbf{n}$ & $\mathbf{R}^{\mathbf{2}}$ \\
\hline 16.05 & 0.127 & 0.547 & 0.9378 & 1.8323 & 0.39 & 0.9794 \\
\hline
\end{tabular}

Table 2: Isotherm Parameters for Adsorption of oxyfluorfen onto aluminum at current densities $75 \mathrm{~mA} / \mathrm{cm}^{2}$.

\begin{tabular}{|c|c|c|c|}
\hline & $\mathrm{Fe}^{+2}\left(\mathbf{K g} / \mathbf{m}^{3}\right)$ & $\mathrm{Fe}^{+3}\left(\mathbf{K g} / \mathbf{m}^{3}\right)$ & $\mathrm{Al}^{+3}\left(\mathbf{K g} / \mathbf{m}^{3}\right)$ \\
\hline Oxyfluorfen & 0.0016 & 0.001 & 0.00050 \\
\hline
\end{tabular}

Table 3: Mass of loss from Fe and Al electrode.

\section{m=I.A.M.t/V.Z.F}

where $\mathrm{m}$ is the mass of the anode material dissolved $(\mathrm{g})$, I the current density $\left(\mathrm{A} \cdot \mathrm{m}^{-2}\right)$, A the active electrode area $\left(\mathrm{m}^{2}\right), \mathrm{M}$ the molar mass of the anode material $\left(\mathrm{g} \cdot \mathrm{mol}^{-1}\right)$, $\mathrm{t}$ electrolysis time (s), V volume of the reactor $\left(\mathrm{m}^{3}\right), \mathrm{z}$ the number of electrons transferred, and $\mathrm{F}$ the Faraday's constant $\left(96,485 \mathrm{C} \mathrm{mol}^{-1}\right)$. The cathode dissolution was not considered according to equation (19). The maximum possible mass of $\mathrm{Fe}$ and $\mathrm{Al}$ electrochemically generated from sacrificial anodes in Table 3 at optimum condition for each process.

Determine the residual concentration of iron in herbicides samples: It appears to be more of a nuisance than a potential health hazard. Iron in water $0.1 \mathrm{mg} . \mathrm{L}^{-1}$ for ferrous iron and $0.2 \mathrm{mg} . \mathrm{L}^{-1}$ ferric Iron. Water used in industrial processes usually contain less than 0.2 mg. $\mathrm{L}^{-1}$ iron [37]. According to following equation Beer-lambert:

\section{$A=\varepsilon b$ C}

Where $\mathrm{A}$ is absorbance, $\varepsilon$ is the molar absorptivity, $\mathrm{b}$ is the path length of the sample and $\mathrm{C}$ is the concentration of the compound in solution. The concentration measurements of iron (II) was found 0.08 mg. $\mathrm{L}^{-1}$ for oxyfluorfen.

\section{Conclusion}

1. Oxyfluorfen herbicide and COD removal were (98.5\% and 90\%) using $\mathrm{Fe}(99.2 \%$ and $85 \%)$ using S-S and $(96.1 \%$ and $70.5 \%)$ using $\mathrm{Al}$ at $30 \mathrm{~min}$ respectively, electrical energy consumption $\left(15.9,16.65\right.$ and $\left.14.1 \mathrm{KWh} / \mathrm{m}^{3}\right)$ using $\mathrm{Fe}, \mathrm{S}-\mathrm{S}$ and $\mathrm{Al}$ electrodes respectively typical operating conditions: current density $75 \mathrm{~mA} . \mathrm{cm}^{-2}, \mathrm{pH} 5.8$, sodium chloride concentration 1 g. $\mathrm{L}^{-1}$, herbicide concentration $200 \mathrm{mg} . \mathrm{L}^{-1}$, inter-electrode distance 1.0 $\mathrm{cm}$ and temperature $10^{\circ} \mathrm{C}$ using all electrodes.

2. The results were concluded that the electrode material play an important role in electrocoagulation method for treatment of herbicides in aqueous solution.

3. The removal rate of oxyfluorfen followed first order reactions using Fe, S-S and Al electrodes with rate constant $0.025,0.023$ and $0.12 \mathrm{~min}^{-1}$ respectively.

4. The oxyfluorfen adsorption was best fitted by the Freundlich adsorption isotherm and the results were in good agreement with the experimental data.

\section{References}

1. Ayranci E, Hoda N (2004) Adsorption of bentazon and propanil from aqueous solutions at the high area activated carbon-cloth. Chemosphere 57: 755-762.

2. Yih RY, Swithenbank C (1975) New potent diphenyl ether herbicides. J Agric Food Chem 23: 592-593.

3. Mohamed AT, El-Hussein AA, Siddig El, Marmar A, Osman AG (2011) Degradation of oxyfluorfen herbicide by soil microorganisms biodegradation of herbicides. Biotechnology.

4. Fasfous II, Rehan SE, Dawoud JN (2012) Simultaneous Preconcentration of Oxyfluorfen and Chlorpyrifos in Environmental Water Samples Using Spent Coffee Grounds as SPE Sorbents.
5. Yen JH, Sheu WS, Wang YS (2003) Dissipation of the herbicide oxyfluorfen in subtropical soils and its potential to contaminate groundwater. Ecotoxicology and environmental safety $54: 151-156$.

6. Aksu Z, Kabasakal E (2005) Adsorption characteristics of 2, 4-dichlorophenoxyacetic acid (2, 4-D) from aqueous solution on powdered activated carbon. Journal of Environmental Science and Health Part B 40: 545570.

7. Giri RR, Ozaki H, Ishida T, Takanami R, Taniguchi S (2007) Synergy of ozonation and photocatalysis to mineralize low concentration 2,4-dichlorophenoxyacetic acid in aqueous solution. Chemosphere 66: 1610-1617.

8. Sun YF, Pignatello JJ (1993) Photochemical-reactions involved in the total mineralization of 2, 4-d by Fe3+/H2O2/UV. Environmental science \& technology 27: 304-310.

9. Alfano OM, Brandi RJ, Cassano AE (2001) Degradation kinetics of 2, 4-D in water employing hydrogen peroxide and UV radiation. Chemical Engineering Journal 82: 209-218.

10. Santacruz G, Bandala ER, Torres LG (2005) Chlorinated pesticides (2, 4-D and DDT) biodegradation at high concentrations using immobilized Pseudomonas fluorescens. Journal of Environmental Science and Health Part B 40: 571-583.

11. Siampiringue M, Wong W, Chung P, Koriko M, Tchangbedji G, et al. (2014) Clay and soil photolysis of the pesticides mesotrione and metsulfuron methyl. Applied and Environmental Soil Science.

12. Behloul M, Grib H, Drouiche N, Abdi N, Lounici H, et al. (2013) Removal of malathion pesticide from polluted solutions by electrocoagulation: Modeling of experimental results using response surface methodology. Separation Science and Technology 48: 664-672.

13. Babu BR, Meera KM, Venkatesan P (2011) Removal of pesticides from wastewater by electrochemical methods-A comparative approach Methods. Sustain Environ Res 21: 401-406

14. Abdel-Gawad SA, Baraka AM, Omran KA, Mokhtar MM (2012) Removal of some pesticides from the simulated waste water by electrocoagulation method using iron electrodes. Int J Electrochem Sci 7: 6654-6665.

15. Ghalwa A, Nasser M, Farhat NB (2015) Removal of abamectin pesticide by electrocoagulation process using stainless steel and iron electrodes. J Environ Anal Chem 2: 1-7.

16. Bernal-Martínez LA, Barrera-Díaz C, Natividad R, Rodrigo MA (2013) Effect of the continuous and pulse in situ iron addition onto the performance of an integrated electrochemical-ozone reactor for wastewater treatment. Fuel 110: 133-140.

17. Mohan N, Balasubramanian N, Basha CA (2007) Electrochemical oxidation of textile wastewater and its reuse. J Hazard Mater 147: 644-651.

18. Carneiro PA, Fugivara CS, Nogueira RF, Boralle N, Zanon MV (2003) A Comparative study on chemical and electrochemical degradation of Reactive Blue 4 dye. Portugaliae Electrochimica Acta 21: 49-67.

19. Siringi DO, Home P, Chacha JS, Koehn E (2012) Is electrocoagulation (EC) a solution to the treatment of wastewater and providing clean water for daily use. ARPN Jounal of Engineering and Applied Science 7: 197-204.

20. Ghalwa A, Nasser M, Farhat NB (2015) Removal of abamectin pesticide by electrocoagulation process using stainless steel and iron electrodes. J Environ Anal Chem 2: 1-7.

21. Mollah MY, Morkovsky P, Gomes JA, Kesmez M, Parga J, et al. (2004) Fundamentals, present and future perspectives of electrocoagulation. J Hazard Mater 114: 199-210.

22. Khandegar V, Saroha AK (2013) Electrocoagulation for the treatment of textile industry effluent--a review. J Environ Manage 128: 949-963.

23. Awad HS, Galwa NA (2005) Electrochemical degradation of Acid Blue and Basic Brown dyes on $\mathrm{Pb} / \mathrm{PbO} 2$ electrode in the presence of different conductive electrolyte and effect of various operating factors. Chemosphere 61: $1327-1335$.

24. Sengil IA (2006) Treatment of dairy wastewaters by electrocoagulation using mild steel electrodes. Journal of hazardous materials 137: 1197-1205.

25. El-Sayed GO, Awad MS, Ayad ZA (2014) Electrochemical Decolorization of Maxilon Red GRL Textile Dye. International Research Journal of Pure and Applied Chemistry. 4: 402. 
Citation: Ghalwa NM, Musabeh AZ, Farhat NB (2017) Performance Efficiency of Electrocoagulation Adsorption Process of Oxyfluorfen Herbicide from Aqueous Solutions Using Different Anodes. J Environ Anal Toxicol 7: 448. doi: 10.4172/2161-0525.1000448

26. Dalvand A, Gholami M, Joneidi A, Mahmoodi NM (2011) Dye removal, energy consumption and operating cost of electrocoagulation of textile wastewater as a clean process. CLEAN-Soil, Air, Water 39: 665-672.

27. Daneshvar N, Sorkhabi HA, Kasiri MB (2004) Decolorization of dye solution containing Acid Red 14 by electrocoagulation with a comparative investigation of different electrode connections. Journal of hazardous materials 112: 55-62.

28. Liu H, Zhao X, Qu J (2010) Electrocoagulation in water treatment. InElectrochemistry for the Environment 245-262.

29. Kamaraj R, Ganesan P, Lakshmi J, Vasudevan S (2013) Removal of copper from water by electrocoagulation process-effect of alternating current (AC) and direct current (DC). Environ Sci Pollut Res 20: 399-412.

30. Dash BP, Chaudhari S (2005) Electrochemical denitrificaton of simulated ground water. Water research 39: 4065-4072.

31. Vermeulan TH, Vermeulan KR, Hall LC (1966) Pore- and Solid-Diffusion Kinetics in Fixed-Bed Adsorption under Constant-Pattern Conditions. Ind. Eng. Chem. Fundamen 5: 212-223.
32. Oguz E (2004) Adsorption characteristics and kinetics of $\mathrm{Cr}(\mathrm{VI})$ on Thuja Orantalis. Colloids Surf 252: 121-128.

33. Hutson ND, Yang RT (2000) A Dynamic Approach to Brownian Coagulation of Electrostatically Stabilized Colloid Particles. Adsorption J. Colloid Interf Sci 189.

34. Dalvand A, Gholami M, Joneidi A, Mahmoodi NM (2011) Dye removal, energy consumption and operating cost of electrocoagulation of textile wastewater as a clean process. CLEAN-Soil, Air, Water 39: 665-672.

35. Eslami A, Moradi M, Ghanbari F, Mehdipour F (2013) Decolorization and COD removal from real textile wastewater by chemical and electrochemical Fenton processes: a comparative study. J Environ Health Sci Eng 11: 31

36. Mechelhoff M, Kelsall GH, Graham NJ (2013) Super-faradaic charge yields for aluminium dissolution in neutral aqueous solutions. Chem Eng Sci 95: 353-359.

37. World Health Organization (1988) Requirements of Vitamin A, Iron, Folate, and Vitamin B12: Report of a joint FAO/WHO Expert Consultation (No. 23). Food \& Agriculture Org. 